\title{
Theoretical fundamentals and metrics of country competitiveness in the fourth industrial revolution
}

\section{Teorijske osnove i metrika konkurentnosti zemalja u četvrtoj industrijskoj revoluciji}

\author{
Vladimir Stojanovića ${ }^{a^{*}}$ \\ ${ }^{a}$ Faculty of Economics, University of Niš, Serbia
}

\begin{abstract}
On the one hand, the paper attempts to determine the complex phenomenon of competitiveness of countries conceptually and essentially, and on the other hand, it presents the competitiveness of the ten most competitive countries in the world, Serbia and 8 selected countries, according to Global Competitiveness Index 4.0. A wide range of views of economic theorists, concerning the justification of using the concept of country competitiveness, was stated. The position on the justification of treating the competitiveness of countries was stated and it was concluded that the basis of this concept is the increase in productivity as the most important determinant of long-term economic growth, i.e. the improvement of all significant factors that enable more efficient use of factors of production. The concept is based on the observation of economic growth as the sum of growth factors of production - i.e. labor and capital - and total factor productivity, as measures offactors that cannot be explained by labor, capital or other inputs. Also, the paper provides an analysis of the indicators of competitiveness and innovation ability of the ten most competitive countries in the world, the Republic of Serbia and selected countries from its surroundings in 2019, based on data from the World Economic Forum. It was stated that Serbia and the countries from its surroundings lag far behind the most competitive and most innovative countries in the world. However, a relatively favorable position of Serbia in terms of innovation capacity was noted, which leaves room for Serbia to make significant and faster progress in terms of improving international competitiveness than most of the observed countries in the region.
\end{abstract}

Keywords: country competitiveness, innovation capacity of the economy, Global Competitiveness Index 4.0, Serbia, productivity.

Sažetak: U radu se čini pokušaj pojmovnog i suštinskog određenja kompleksnog fenomena konkurentnosti zemalja, s jedne, i dat prikaz konkurentnosti deset najkonkurentnijih zemalja

${ }^{*}$ Corresponding author

E-mail address: vladastjnvc2@gmail.com

This is an open access paper under the license (c) (1) () 
sveta, Srbije i 8 selektovanih zemalja iz okruženja, prema vrednosti Global Competitiveness Index 4.0, s druge strane. Konstatovana je široka lepeza stavova ekonomskih teoretičara po pitanju opravdanosti korišćenja koncepta konkurentnosti zemalja. Iznet je stav o opravdanosti tretiranja konkurentnosti zemalja i zaključeno je da se u osnovi ovog koncepta nalazi povećanje produktivnosti kao najvažnije odrednice dugoročnog ekonomskog rasta, odnosno unapređenje svih značajnih činilaca koji omogućavaju efikasniju upotrebu faktora proizvodnje. Koncept je zasnovan na posmatranju privrednog rasta kao zbira rasta faktora proizvodnje - tj. radne snage i kapitala - $i$ ukupne faktorske produktivnosti, kao mere faktora koji se ne mogu objasniti radom, kapitalom ili drugim inputima. Takođe, u radu se daje analiza pokazatelja konkurentnosti i inovacione sposobnosti deset najkonkurentnijih zemalja u svetu, Republike Srbije i selektovanih zemalja iz njenog okruženja u 2019. godini, na osnovu podataka Svetskog ekonomskog foruma. Konstatovano je veliko zaostajanje Srbije i zemalja iz njenog okruđenja za najkonkurentnijim $i$ najinovativnijim zemljama sveta. Međutim, konstatovan je i relativno povoljan položaj Srbije u pogledu inovacionog kapaciteta što ostavlja prostor Srbiji da značajnije i brže napreduje u pogledu unapređenja međunarodne konkurentnosti od većine posmatranih zemalja u okruženju.

Ključne reči: konkurentnost zemlje, inovaciona sposobnost privrede, Global Competitiveness Index 4.0, Srbija, produktivnost.

\section{Introduction}

The category of competitiveness is one of the main research topics in economics during the last decades. It is one of the most frequently treated concepts in recent economics (Garelli, 2004). However, despite this fact, it is evident that in theoretical and empirical research there is no generally accepted explanation of its content.

Due to the extreme complexity of the phenomenon of competitiveness, almost all of its theoretical analyzes are inextricably linked with its pronounced conceptual simplifications. The simple reason for this is the fact that only a small number of the considered drivers of improving the country competitiveness can be taken into account when researching this phenomenon. Precisely, due to the complex nature of competitive processes, the conceptual definition of the category of competitiveness is often imprecise and often complicated to understand (Snieška \& Bruneckienè, 2009).

Approaches to researching the phenomenon of competitiveness are significantly different. This is evidenced by the fact that a number of analysts strongly argue that competitiveness has the characteristics of the "natural law of the modern market economy" (Kitson et al., 2004; Kitson, Martin, \& Sunley, 2006; 2011), while a small number of researchers believe that the definition of competitiveness can be almost entirely conceptually identified with the category of productivity and therefore there is no place to talk about competitiveness as an economic category (Krugman, 1995; Ketels, 2006).

The subject of research in this paper is: a) theoretical explication of the conceptual and essential definition of the category of competitiveness of countries and b) presentation of competitiveness and innovation ability of the ten most competitive countries, Serbia and neighboring countries, according to the Global Competitiveness Index 4.0 from 2019. 


\section{Conceptual and essential determination of countries' competitiveness}

The category of the country's competitiveness is increasingly the focus of theoretical and empirical research. The ability to adapt to changes that occur in the global market is based on factors such as the size of investments, the ability to innovate, production infrastructure, etc. However, the economic performance of countries must be combined with political and social factors that also affect the quality of functioning of the national economy.

Country competitiveness should be understood as a set of factors, policies and institutions that determine the sustainable level of prosperity that can be achieved in the economy. Although it is obvious that the competitiveness of one country is essentially related to the quality of its economic performance, the fact is that this category is primarily seen as a relative position to other countries, and far less to its accumulated wealth.

Identifying the competitiveness of a country with its ability to place goods and services on foreign markets does not correspond to modern economic conditions. At the same time, it is not disputed that the incentives to improve competitiveness are mostly related to companies, but there are a number of reasons why a country should be as competitive as possible in global relations.

In the broadest sense, the competitiveness of a country is based on quantifying and comparing its key performance indicators and the achieved standard of living of the population. In a somewhat reduced form, the concept of a country's competitiveness shows its ability to export products to the world market, that is, its potential to increase productivity. It is in fact a measure of a country's ability to produce goods and services using its own human, financial, natural and many other productive resources. Country's competitiveness means a measure of production of goods and provision of services, which under free and fair market conditions meets the criteria of the international market and at the same time affects the increase of real incomes of its citizens (OECD, 1992).

The country's ability to be internationally competitive is determined through a number of internal and external factors, such as: human and natural resources, infrastructure, management, capital, government interventions and the technological capability of enterprises. It is based on high-quality production performance and the economic ability to produce outputs with the highest possible productivity, which in turn generates a high level of real earnings. Competitiveness is closely linked to rising living standards, greater employment opportunities, and the country's ability to meet its international obligations.

The World Economic Forum defines a country's competitiveness as "a set of institutions, policies and factors that determine its level of productivity." The country's competitiveness speaks to its ability to provide its population with growing economic prosperity. The focus on productivity, reflects the goal of identifying determinants of sustainable prosperity, whether they function through inputs, such as skills and capital, or through the efficiency with which their inputs are employed. Focusing on input and 
efficiency is problematic, for conceptual and practical reasons. Conceptually, they are not determined independently. In practice, the calculation of inputs and efficiency levels has significant limitations.

Trabold (1995) as particularly important aspects of the country's competitiveness emphasizes its ability to sell in the global market (exports), attracts investment (location), adjusts the structure of the economy and creates and increases disposable income. Bienkowski (2008), determines a country's competitiveness in light of its ability to achieve economic growth higher than other observed countries and thus increase the living standards of its population through changing its economic structure and adjusting to international market trends.

Identifying the country's competitiveness with its ability to place goods and services on foreign markets is a narrow approach and does not meet modern business conditions. Also, the interpretation of a country's competitiveness as a way to increase wealth (Aiginger, 2006) ultimately comes down to labor productivity, since higher national income implies higher productivity.

Competitiveness as a result of a country's ability to generate innovation in order to achieve or maintain an advantage over other countries in a number of key industries was first defined by Porter (1990) in his research. Further work emphasizes that within knowledge-based economies, countries should primarily develop specialization in order to achieve a high standard of living for the population (Huggins et al., 2008).

Krugman (1994) believes that the concept of the country's competitiveness is fundamentally extremely wrong and that it represents a „dangerous obsession“ of the proponents of this concept. This is because any analogy between a country and a company is absolutely unacceptable, because unsuccessful companies will be pushed out of the market in case of non-competitiveness, which does not apply to individual countries. In addition, when companies compete for market share, then the success of one is created at the expense of less success of the other company. This rule cannot be applied to countries, because the success of individual countries improves rather than harms other countries. If competitiveness makes sense, then it is simply another way to express productivity because improving living standards essentially depends on the rate of productivity growth.

The country's competitiveness should be viewed on the basis of its own ability to create a high (and growing) standard of living, as well as real income. A much broader view of well-being is that it will lead, for example, not only to the improvement of competitiveness that includes income (consumption), but also to the achievement of numerous social and environmental goals.

Country competitiveness means a measure of production of goods and provision of services, which under free and fair market conditions meets the criteria of the international market and at the same time acts in the direction of increasing the real incomes of its citizens. In this context, the concept of the country's competitiveness is a legitimate macroeconomic and in the analytical sense absolutely acceptable category. It is a concept within which special analytical instruments and standards 
have been developed that are applied to all levels of the country's competitiveness analysis. It is an instrument of economic analysis that is continuously developed and improved, which is completely logical when you consider the global race of countries, regions and clusters to increase competitiveness (Dragičević, 2012).

The country's competitiveness is determined, on the one hand, by the ability of economic institutions to create favorable conditions, and on the other hand, by the ability of companies and branches to use those conditions to create and develop sustainable competitive advantages. It can be viewed as a relative indicator of the appropriate level of efficiency of production, distribution and sale of goods in both domestic and international markets in order to increase its own economic potential and level of socio-economic development. Hence, it can be concluded that the essence of the country's competitiveness presupposes an appropriate level of competitiveness of domestic companies and their products. The country cannot appear as an entity that creates a competitive advantage because that is the sphere of activity of the company. In fact, the "creators" of competitiveness are, primarily, companies and industries, since only they can realize it. The country appears, primarily, as an entity responsible for creating an institutional environment as a condition for the formation of competitiveness.

It is certainly easier to define competitiveness at the enterprise level in relation to the conceptual definition of a country's competitiveness. This is for the simple reason that companies compete with each other internationally, in order to conquer the desired market or reach the necessary resources. In this case, competitiveness strategies and achieved results can be objectively defined and quantified. However, when the competitiveness of countries is observed, then the situation becomes more complicated due to the fact that the companies of the observed countries compete with each other in radically different ways. Countries compete with each other to attract new foreign direct investment and preserve existing foreign investors. In this context, government officials play a significant role as they act on the physical infrastructure and human capital in the country, then set the rules for doing business, create and implement tax policy and provide support and various types of incentives to businesses (Barton, et al., 2007).

The concept of country competitiveness includes both static and dynamic components. Although a country's productivity is determined by its ability to produce a high level of income, it is at the same time one of the key determinants of the return on investment.

Modern economies operate in a global marketplace, where the success of each actor depends on its ability to be competitive, innovative and flexible. In the complex competitive relations that rule the world economic scene, countries build their path to international success on the basis of improving the business economy and improving the competitiveness of individual companies. The country's growing competitiveness speaks to its ability to succeed in markets, leading to a highly productive economy and a higher standard of living, greater employment opportunities, as well as its more pronounced ability to meet its international obligations. 


\section{Approaches in researching the competitiveness of the country}

In economic theory, there are two approaches to researching a country's competitiveness. The first approach is based on differences in relative prices between countries, and the second is based on differences in productivity (Crespo Rodríguez \& Pérez-Quirós \& Segura, 2012).

The competitiveness of the country based on the differences in relative prices presupposes the consideration of the participation of the observed country in the world market. The view of competitiveness is based on the cost ratio, i.e. the market shares of the observed country in relation to other countries. Consequently, this makes competitiveness a zero-sum game, which means that one country can improve its own competitiveness, only at the expense of reducing the competitiveness of another country. In order to achieve this goal, average rents are kept at a very low level and the devaluation of the domestic currency is not uncommon. It is believed that cheap labor and cheap domestic currency make one country more competitive on the world market compared to other countries. However, this understanding of competitiveness is at odds with the country's economic progress and the high standard of living of its inhabitants. This is for the main reason that low wages indicate a lack of competitiveness, on the one hand, while with the devaluation of the national currency, the country sells its products and services at low prices, on the other hand. Competitiveness, viewed in this way, is motivated by concern for external equilibrium. Accordingly, countries are "competitive" if their basic macroeconomic aggregates are in balance. This perspective is focused on short- and medium-term growth.

A country competitiveness approach based on differences in relative prices between countries is important for organizations which task is to monitor and manage macroeconomic balances. Their assessment is that countries that lose competitiveness due to rising relative labor costs are at risk of increasing macroeconomic imbalances.

The second approach to perceiving the country's competitiveness tries to find an acceptable answer to the question of what the key determinants of countries' economic prosperity are. The standard of living is the result of the achieved productivity in the observed economy, measured by the value of produced goods per unit of total resources available to the economy (human, financial, natural capital). In short, the level of productivity predominantly determines the level of economic prosperity in the observed country. The focus on productivity reflects the need to identify key determinants of sustainable prosperity, regardless of whether their impact is manifested through the growth in the amount of factors of production used or through the efficiency with which factors are used in the production of goods. Focusing on inputs and efficiency individually is problematic, both conceptually and practically. Conceptually, they are not determined independently. In practice, the calculation of inputs and efficiency levels has significant limitations.

Underlying the concept of competitiveness of a country treated by productivity levels is the view that location potential for value creation based on available factors of production is by far the most important determinant of national competitiveness 
(Porter, 1990; Porter 2000; Delgado et al., 2014). The concept is inspired by research into differences in variability in prosperity and long-term economic growth rates of individual countries. From the macroeconomic perspective, the drivers of the longterm economic growth rate are observed. This perspective focuses on the long term. It is assumed that costs and salaries are automatically "returned" to balance. Countries where there is a loss of competitiveness in terms of slowing economic dynamics are environments where prosperity has declined. Thus, productivity is a key driver of differences in prosperity in different locations. It is also connected with a set of policies in areas such as infrastructure investment, research and innovation as well as access to finance. The debate is more focused on which specific policies are best applied to support productivity growth, rather than whether such policies are generally useful or not. Productivity is a key driver of economic growth and therefore a key goal of competitiveness improvement policy. But, keeping in mind the focus on productivity, it is important to take into account the level of costs as an important prerequisite for improving the country's competitiveness. First, the relationship between productivity and cost is critical to the relative attractiveness of a company's location. Second, the relationship between productivity and costs is an important indicator of macroeconomic balance. Wages that are above productivity levels can cause macroeconomic imbalances. Increasing demand, driven by capital inflows, growing loans or growing public debt, may encourage wages to be set above sustainable productivity levels.

If the previous remarks are taken into account, then the modern understanding of competitiveness comes down to productivity. Many authors believe that the definition of competitiveness refers to productivity that measures the value of goods and services per unit of factors, produced in a given territory. Others insist on distinguishing a country's competitiveness from its productivity. Competitiveness must be distinguished from productivity, which is measured by the amount of production per input size (Samuelson \& Nordhaus, 2011). In short, competitiveness aims to achieve higher productivity that affects the growth of living standards of citizens.

Competitiveness based on productivity corresponds to economic development and high living standards of the population, which means adequately paid labor, high returns on capital, etc. Productivity, therefore, should be the real goal of any economy, not an export in itself. Only an increase in exports of products and services, which can be efficiently produced and placed, has an effect on increasing national productivity.

Competitiveness understood in this way is not an isolated phenomenon, but an interdisciplinary phenomenon that connects business strategy, macroeconomic policy, legal and regulatory reform, education, competitiveness policy and many other economic, business and social factors in creating a single strategic plan to create greater added value.

The competitiveness of a country should be seen in a dynamic context, since it is a function of time. It should also be noted that sectors of the national economy are not always competitive at the same level in the global market. Companies and industries that are leaders at the moment may lose this advantage in the long run, in favor of foreign competitors. The competitiveness function is dynamic and multifactorial. 
There is agreement that improving a country's economic performance does not have to be at the expense of another (i.e. the country is not necessarily in a position to win or lose).

The high level of national competitiveness is in the function of attracting investments, more pronounced technology transfer, expansion of business activities of the company. In contrast, low ratings and evaluation serve as indicators of underestimation by the governments of certain countries and the need to foster an improved national environment. Each country feels the need to compare itself with other countries in terms of a certain set of criteria, which give a picture of its ability to withstand international competition in the domestic and global markets.

There is a large number of researches that measure competitiveness in different ways, and some more significant ones will be briefly pointed out below. One of these studies assesses the competitiveness of countries in relation to selected factors. For example, Odehnal et al. (2012) measures the competitiveness of Ukrainian regions. For the needs of their analyzes, they selected several socio-economic indicators from different activities. They used factor analysis and its results to conclude that one out of the four input variables which were analyzed, explained almost half of the variations. The following factors were further analyzed: economic development factor, activity development factor, migration and employment factor, labor market factor and development factor. In their research, Önsel et al. (2008) examine the competitiveness of countries, while declaring the fact that gross domestic product as an indicator has many limitations in terms of accurate grouping of countries through cluster analysis. Within Section 11, 178 criteria were set, while three main indicators were measured: the so-called macroeconomic index, the index of public institutions and the technology index. The results of their analysis are clusters of countries based on their level of competitiveness and a draft list of criteria for further analysis conducted using neural networks. The final groups of countries reflect the most commonly used indicator, gross domestic product.

Ulengin et al. (2002) assess competitiveness based on an assessment of the World Competitiveness Index by the International Institute for Management Development. One of its components is the gross domestic product. When the research variables are studied in more detail, it is obvious that a number of explained parameters significantly correlate with the given assessment of the researched country, which can negatively affect the outcomes and strongly limit the quality of interpretation of the analysis.

Rozmahel et al. (2014) have a significantly different research character when measuring competitiveness. Emphasis is placed on the assessment of the infrastructure of the European Union member states. The authors of the research primarily focus on the new EU members, although the analysis is performed using data from all member states or potential future members in a given period of time. The research implies that differences between countries are gradually being eliminated over time.

There are studies that have explored differences between countries in terms of innovation performance and competitiveness. Sener and Saridogan (2011) attempted 
to investigate the effects of global competitive strategies and transfer mechanisms focused on science, technology, and innovation on the economic growth of highincome OECD countries. Their results showed the countries that have economic policies and strategies based on science, technology and innovation. These countries have great superiority and a sustainable competitive advantage not only in global competitiveness, but also in economic growth and development that lead to the country's wealth and prosperity. Hudec and Prochadzkova (2015) conducted research in the Visegrad Group countries and regions focusing on innovative performance and efficiency. Based on their research, the country factor does not matter much in building competitiveness.

Many international institutions and organizations research different aspects of competitiveness, assessing and ranking countries or companies according to the level of competitiveness achieved, defining competitiveness for their needs and compiling criteria and methods for measuring competitiveness. Their goal is to use analyzes and assessments to show the achieved level of competitiveness of different countries as a whole and by individual areas, i.e. competitiveness factors, in order to enable governments and other institutions and organizations to create effective policies in the field of competitiveness development, while eliminating territorial inequalities and differences.

\section{Competitiveness in industry 4.0}

One of the leading international institutions engaged in competitiveness research at the global level is the World Economic Forum. Each year, experts from the World Economic Forum evaluate and publish information on global competitiveness, and their Global Competitiveness Index - GCI consists of a number of factors that support the competitiveness of individual countries. Global Competitiveness Index - GCI has been published since 2004 .

Globalization and the fourth industrial revolution created new opportunities, but also disturbances and an even bigger gap between different economies and countries. With this in mind, in 2018 the World Economic Forum presented the new Global Competitiveness Index 4.0 as a new economic roadmap, based on forty years of experience in monitoring and comparing long-term competitiveness factors.

The Global Competitiveness Index 4.0 (GCI 4.0) provides a detailed overview of the factors and characteristics that determine productivity, growth, and human development in the era of the Fourth Industrial Revolution. The index is based on economic growth theory and aims to measure the drivers of "total factor productivity" (TFP), i.e. the part of economic growth that is not explained by the growth of production factors. Total factor productivity can be interpreted as the use of production factors wisely and which is the main determinant of long-term economic growth. Simply put, total factor productivity shows how efficiently units of labor and capital combine to create production.

The Global Competitiveness Index 4.0 is an annual indicator that allows economic policy makers to assess their progress against a range of factors that determine 
productivity by combining the values of 103 individual indicators, obtained from a combination of data from international organizations (usually national statistical organizations) conducted by the World Economic Forum's Executive Opinion Survey, which aims to supplement data that cannot be obtained from official statistical sources (so-called soft data). All indicators that make up the Global Competitiveness Index 4.0 are organized into 12 "pillars": Institutions; Infrastructure; Application of ICT; Macroeconomic stability; Health; Skills; Product market; Job market; Financial system; Market size; Business Dynamics and Innovation Capacity.

The performance of one country in the overall results of the Global Innovation Index, as well as all its components, is the "result of progress" on a scale from 0 to 100, where 100 represents the "upper limit", i.e. the ideal country where the problem ceases to be a constraint on productivity growth. Each country should aim to approach the boundaries of each component of the index. Global Competitiveness Index 4.0. allows economies to track progress over time. This approach emphasizes that competitiveness is not a zero-sum game between countries (that the gain of one country does not mean the loss of another) and that it is achievable for all countries regardless of the initial level of development and current competitiveness.

In 2019, the Global Competitiveness Report published the latest data on the values of the Global Competitiveness Index 4.0. which shows competitiveness and provides insight into the economic prospects of 141 countries, which accounts for $99 \%$ of world GDP. The report itself is designed to help policymakers, business leaders and other stakeholders shape their economic strategies in the era of the Fourth Industrial Revolution.

Results of the Global Competitiveness Index 4.0. for 2019 point to a deep competitiveness deficit that needs to be addressed urgently in order to restore productivity and growth to improve living standards. The obtained results indicate that, on average, most economies are still far from the "limit" of competitiveness - the overall ideal in all factors of competitiveness. The average GCI score for 141 analyzed economies is 60.7 index points, which means that the "distance to the border" is almost 40 points. The effect also differs among the 12 pillars of the index. At 9 of the 12 pillars, the average global gap is more than 30 points. Advanced economies perform consistently better than the rest of the world, but overall, they still have 30 points less than the limit. Singapore, the best player in the overall standings, still does not score 15 points from the ideal (Schwab, 2019).

The Global Competition Report for 2019 also shows that 10 years since the financial crisis, while central banks have invested nearly $\$ 10$ billion in the global economy, investments in productivity improvements, such as new infrastructure, research and development and skills development in the current and future workforce was insufficient. When monetary policy begins to run out of money, it is crucial that economies rely on fiscal policy, structural reforms, and public incentives to allocate more resources to a range of productivity factors to take full advantage of the new opportunities offered by the fourth industrial revolution. 
The report further points out that the global economy is poorly prepared for the downturn after a lost decade for productivity measures. The persistent weaknesses of the drivers of productivity growth, as highlighted, are the main culprits for the poor performance and malfunction of the global economy in the last decade. Productivity growth began to slow significantly before the financial crisis and slowed after that. The financial crisis may have contributed to this slowdown through the "productivity hysteresis." Furthermore, apart from strengthening regulations on the financial system, many structural reforms aimed at reviving productivity have not taken place.

Experts from the World Economic Forum point out that policymakers must look beyond monetary policy and pay attention to the possibilities of other policies, such as fiscal, investment and incentives to revive productivity growth. They point out that since the Great Recession, policymakers have kept the global economy primarily a loose and unconventional monetary policy. But despite massive liquidity injections four of the world's largest central banks, which injected more than $\$ 10$ billion between 2008 and 2017, productivity growth has continued to stagnate over the past decade. Although loose monetary policy has mitigated the negative effects of the global financial crisis, it may also have contributed to declining productivity growth by encouraging misallocation of capital.

The Global Competitiveness Report 2019 shows that there are no inherent trade-offs between economic growth and social and environmental factors if we adopt a holistic and longer-term approach. Although few economies currently follow such an approach, it has become necessary for all economies to develop new inclusive and sustainable pathways to economic growth if we are to meet the goals of sustainable development. Bold leadership and proactive policy-making, according to SEF experts, are needed, often in areas where economists and policy professionals cannot benefit from past experiences. The report presents the most promising new paths, policies and incentives, identifying "win-win" spaces, but it also points to the choices and decisions that leaders must make in determining the path to achieving the primary goals: growth, inclusion and sustainability.

In order to achieve the previous three goals, it is necessary to increase productivity, and this is possible in the long run only by finding a balance between technological integration and investment in human capital. For that reason, experts from the World Economic Forum point out that it is a challenge that technology and innovation become the DNA of the economy. However, according to these authors, an even greater challenge is how to ensure that governments, i.e. policy makers, ensure that as many citizens in their countries benefit from the development of technology and innovation. Therefore, the necessity of applying a holistic approach through investments in human capital and measures to mitigate the unintended harmful effects of technological progress on income distribution and social cohesion is pointed out. It is highlighted that in the so-called Sumpter process of "creative destruction", creativity must be encouraged and "destruction" must be managed. Increased worker insecurity, skills gap, excessive market concentration, corrosive effects on social fabric, regulatory loopholes, data privacy issues and cyber warfare are just some of the potential negative effects that governments must mitigate in order to improve competitiveness and have long-term sustainability. 
In the Global Competitiveness Report for 2019, the authors paid special attention to innovations, the factors that enable them and their impact. The results obtained show that technology management is not sufficiently aligned with innovation in most countries, including some of the largest and most innovative. That is why countries need to improve the adaptability of talent; that is, to enable their workforce to contribute to the process of creative destruction and to confront its disturbances. Talent adaptability also requires a well-functioning labor market that protects workers, not jobs. The report reveals that in several countries with significant innovation and technological opportunities such as Korea, Italy, France and Japan, insufficient talent development can increase the risk of negative social consequences. Emerging economies, with growing innovation capacities, such as China, India and Brazil, also need to balance technological integration and investment in human capital.

The Report makes it clear that just focusing on economic growth without an equal focus on making growth inclusive and environmentally sustainable can have dire consequences for the planet and humanity. The acceleration of climate change is already affecting hundreds of millions around the world, and it is likely that people under the age of 60 will witness its radical destabilizing effects on Earth. At the same time, growing inequality, insecurity and lack of social mobility are undermining social cohesion with a growing sense of injustice, perceived loss of identity and dignity, weakening social fabric, undermining trust in institutions, dissatisfaction with political processes and erosion of the social contract.

It has become clear to the authors of the Report that environmental, social and economic programs can no longer be implemented separately and in parallel: they must be integrated into a single sustainable and inclusive growth plan. In this approach, perceived trade-offs between economic, social and environmental factors can be mitigated by adopting a holistic and longer-term approach to growth. This means addressing spillover effects and external, positive and negative, intentional or unintentional, economic policies beyond the direct goals they want.

It is further stated that the very different degrees and speeds in which countries adopt such a holistic approach are growing, reflected in the fact that countries at a similar level of competitiveness achieve very different environmental and social results. For example, Sweden, Denmark and Finland have not only become among the most technologically advanced, innovative and dynamic economies in the world, but also provide better living conditions and better social protection, are more cohesive and more sustainable than other countries.

The basic message given in the Global Competitiveness Report for 2019 is that economic growth is still a key source and factor in improving people's living standards and quality of life. In addition, research into the relationship between competitiveness, prosperity and environmental sustainability shows that there is no balance between competitiveness, the creation of fairer societies that provide opportunities for all and the transition to an environmentally sustainable socio-economic system. It is therefore clear that a new inclusive and sustainable system requires courageous leadership and proactive policy-making, often in areas where economists and public policy professionals cannot use lessons from the past. 


\section{Competitiveness and innovation ability in Industry 4.0 on the example of Serbia and selected countries in the region}

In 2019, according to the Global Competitiveness Index 4.0, the most competitive countries in the world are: Singapore, United States and the Netherlands, followed by Switzerland and Japan. Among the 10 most competitive countries in the world are: Germany, Sweden, United Kingdom, Denmark and Finland.

The observed countries that are leaders in global competitiveness are also leaders in innovation capabilities. Germany, United States and Switzerland, followed by Sweden ( $5^{\text {th }}$ place $)$, Japan $\left(7^{\text {th }}\right.$ place $)$, United Kingdom $\left(8^{\text {th }}\right.$ place $)$ and the Netherlands $\left(10^{\text {th }}\right.$ place) have the largest Innovation capability in the world, in 2019. Good results in terms of Innovation capability are also recorded by the other three countries from the group of 10 most competitive countries in the world: Denmark (11 ${ }^{\text {th }}$ place), Finland $\left(12^{\text {th }}\right.$ place $)$ and Singapore $\left(13^{\text {th }}\right.$ place $)$.

Graph 1. Competitiveness and innovation capacity of the 10 most competitive countries in the world

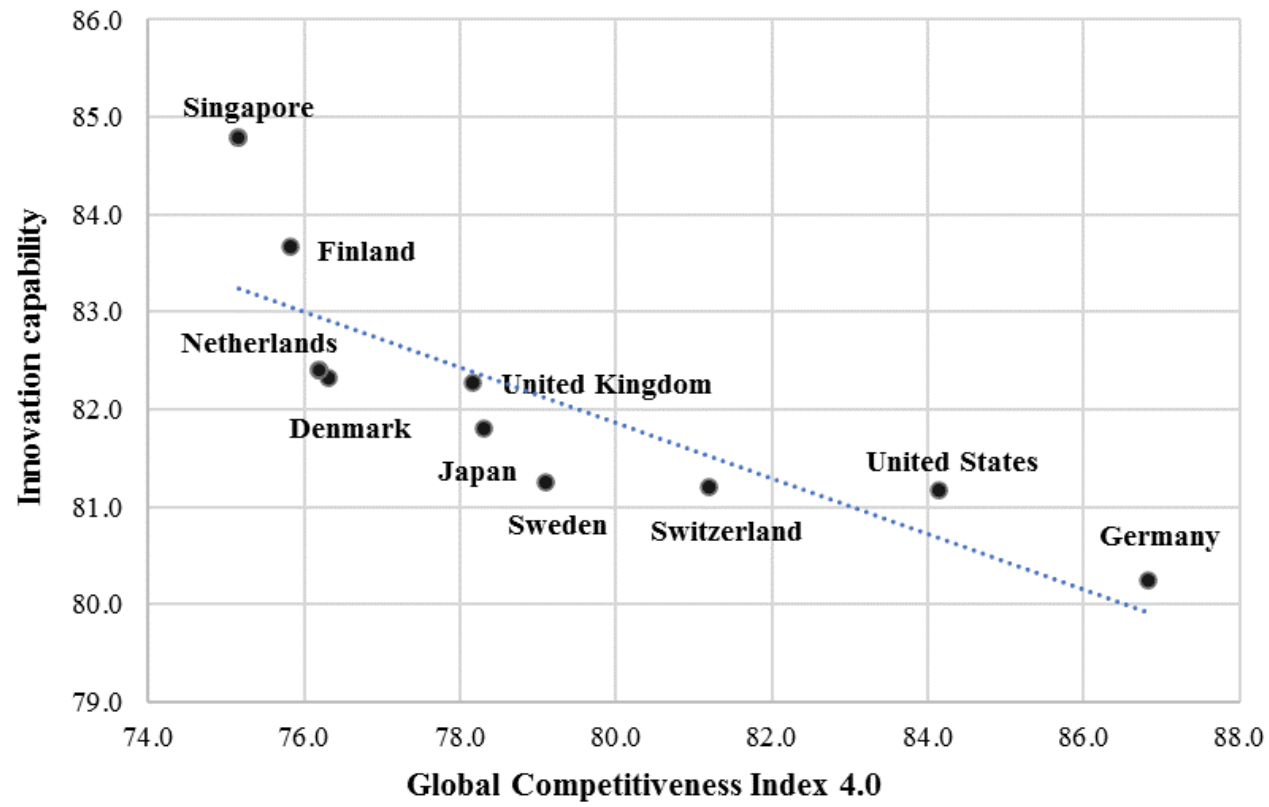

Source: Schwab, K. (2019). The Global Competitiveness Report 2019. Geneva: World Economic Forum.

Serbia and 8 selected countries from the region significantly lag behind the most competitive countries in the world, both in terms of competitiveness and in terms of innovation capacity. In 2019, according to the level of competitiveness, Serbia is ranked $72^{\text {nd }}$ out of 140 observed countries, which is one place better than Montenegro, 9 places better than Albania, 10 places better than N. Macedonia and 20 places better than Bosnia and Herzegovina, but 23 places worse than Romania, 25 places worse than Bulgaria, 37 places worse than Hungary and 72 places worse than Slovenia. 
Graph 2. Competitiveness of the 10 most competitive countries in the world, Serbia and 8 selected countries from the region, according to the value of Global Competitiveness Index 4.0

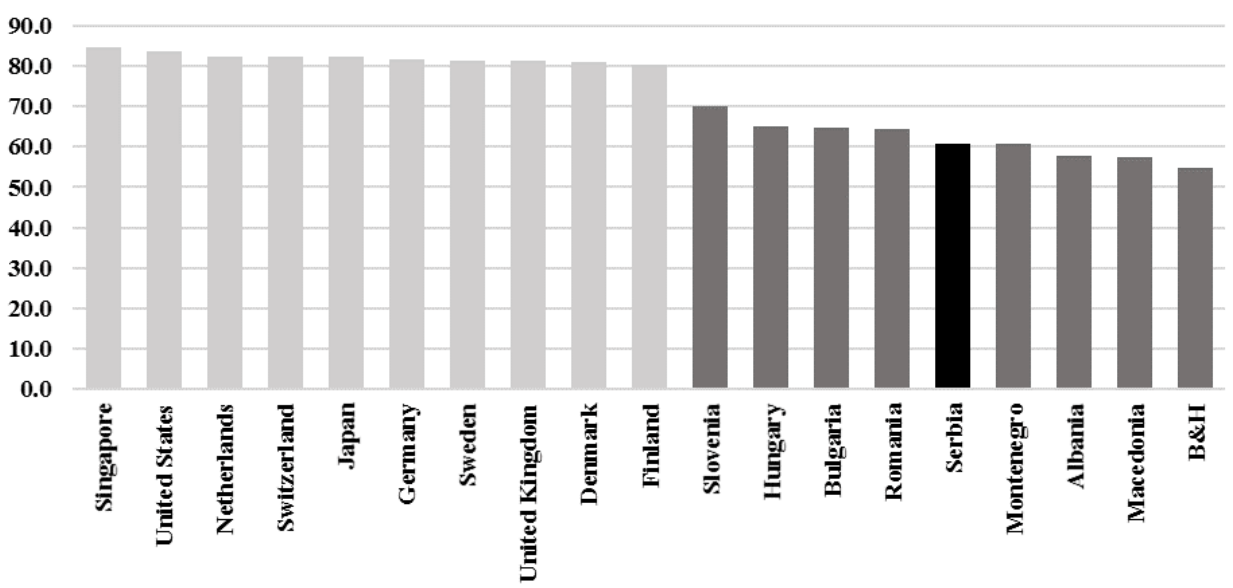

Source: Schwab, K. (2019). The Global Competitiveness Report 2019. Geneva: World Economic Forum.

Although in terms of competitiveness of the 9 observed countries from the surrounding area, Serbia is in the middle, in terms of innovation capacity, the position of Serbia is much more favorable. Out of 140 countries observed in 2019, Serbia is on the $41^{\text {st }}$ place in terms of innovation capacities, which is a weaker result only than Slovenia, which is on the $28^{\text {th }}$ place. This means that Serbia is ranked better in terms of innovation capacities than all other 7 observed countries in the region.

Graph 3. Competitiveness and innovation capacity of Serbia and 8 selected countries from the region

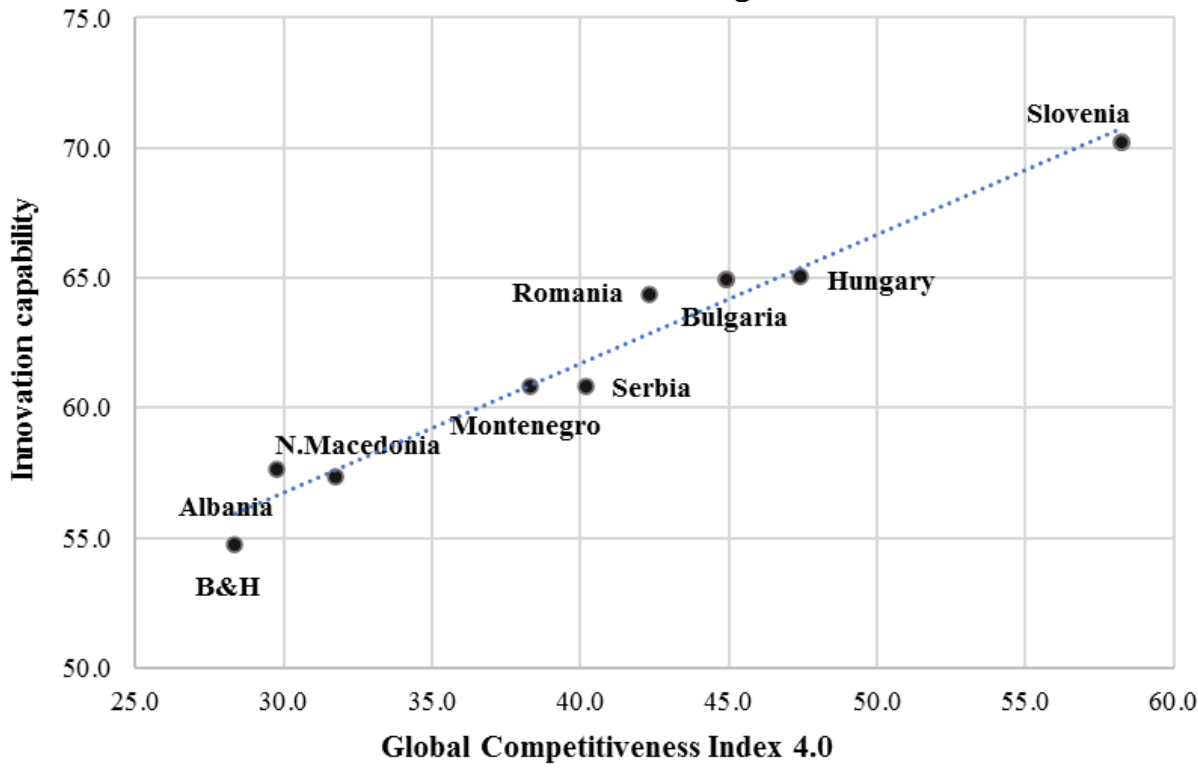

Source: Schwab, K. (2019). The Global Competitiveness Report 2019. Geneva: World Economic Forum. 
Of the observed selected countries from the region, in terms of innovation capacity, Albania is ranked the lowest $\left(117^{\text {th }}\right.$ place out of 140 observed countries $)$ and it is ranked lower than Serbia by 76 places. Bosnia and Herzegovina are ranked $100^{\text {th }}$ (69 places worse than Serbia), Bulgaria is $97^{\text {th }}$ (56 places weaker than Serbia), Hungary is $69^{\text {th }}$ (28 places weaker than Serbia), N. Macedonia is $59^{\text {th }}$ (18 places weaker than Serbia), Montenegro in $55^{\text {th }}$ place (14 places weaker than Serbia) and Romania is in $48^{\text {th }}$ place, which is 7 places weaker than the rank of Serbia.

Serbia's relatively favorable position in terms of innovation capacity leaves room for Serbia to make significant and faster progress both in terms of competitiveness, and consequently in terms of achieving faster economic development than most of the observed countries in the region.

\section{Conclusion}

Competitiveness can be seen as the ability of a country to produce products and provide services on the international market in conditions of free competition, while maintaining and expanding real incomes and improving the living conditions of the population in the long run.

The increasingly pronounced process of globalization of the world economy led by the fourth industrial revolution creates new opportunities for improving international competitiveness, but also increasingly complex challenges and requirements, especially in the field of strengthening and improving the innovation capacity of countries as one of the key factors of their sustainable competitiveness. Strengthening innovation capacity helps countries not only to accelerate the process of structural change and thus create the conditions for dynamic economic growth, but also to improve national competitiveness as a basis for long-term sustainable development in the increasingly complex challenges of global business and competition.

The obtained results show that in 2019, Serbia and the surrounding countries lag far behind the most competitive countries in the world. Specifically, in 2019, Serbia was ranked $72^{\text {nd }}$ out of 140 observed countries according to the level of competitiveness, which is one place better than Montenegro, 9 places better than Albania, 10 places better than N. Macedonia and 20 places better than Bosnia and Herzegovina, but 23 places worse than Romania, 25 places worse than Bulgaria, 37 places worse than Hungary and 72 places worse than Slovenia.

Serbia and 8 selected countries from the region lag significantly behind, both in terms of competitiveness and in terms of innovation capacity. Out of 140 countries observed in 2019 , Serbia is on the $41^{\text {st }}$ place in terms of innovation capacities, which is a weaker result only than Slovenia, which is on the $28^{\text {th }}$ place. This means that Serbia is ranked better in terms of innovation capacities than all other 7 observed countries in the region. 


\section{References}

Aiginger, K. (2006). Competitiveness: from a dangerous obsession to a welfare creating ability with positive externalities. Journal of industry, competition and trade, 6(2), 161-177. https://doi.org/10.1007/s10842-006-9475-6

Barton, J., Jenkins, R., Bartzokas, A., Hesselberg, J., \& Knutsen, H. (2007). Environmental regulation and industrial competitiveness in pollution-intensive industries. Industrial innovation and environmental regulation: developing workable solutions. United Nations University Press, Maastricht, 51-80.

Bienkowski, W. (2008). How much are studies of competitiveness worth? Some reflections on the issue. In Competitiveness of New Europe (pp. 184-198). Routledge.

Crespo Rodríguez, A., Pérez-Quirós, G., \& Segura Cayuela, R. (2012). Competitiveness indicators: The importance of an efficient allocation of resources. Economic Bulletin, (JAN).

Delgado, M., Porter, M. E., \& Stern, S. (2014). Clusters, convergence, and economic performance. Research policy, 43(10), 1785-1799. https://doi.org/10.1016/j.respol.2014.05.007

Dragičević, M. (2012). Konkurentnost: projekt za Hrvatsku. Školska knjiga.

Garelli, S. (2004). Competitiveness of Nations: The Fundamentals. In: IMD World Competitiveness Yearbook, Lausanne, Switzerland.

Hudec, O. \& Prochadzkova, M. (2015). Visegrad Countries and Regions: Innovation Performance and Efficiency. Quality Innovation Prosperity, 19(2), 55-64. https://doi.org/10.12776/qip.v19i2.593

Huggins, R., Johnston, A., \& Steffenson, R. (2008). Universities, knowledge networks and regional policy. Cambridge Journal of Regions, Economy and Society, 1(2), 321-340. https://doi.org/10.1093/cjres/rsn013

Ketels, C. (2006). Michael Porter's competitiveness framework-recent learnings and new research priorities. Journal of Industry, Competition and Trade, 6(2), 115 136. https://doi.org/10.1007/s10842-006-9474-7

Kitson, M., Martin, R., \& Tyler, P. (2004). Regional competitiveness: an elusive yet key concept?. Regional Studies, 38(9), 991-999. https://doi.org/10.1080/0034340042000320816

Kitson, M., Martin, R., \& Tyler, P. (2008). The Regional Competitiveness Debate, Programme on regional innovation. The Cambrigde MIT Institute.

Kitson, M., Martin, R., \& Tyler, P. (2011). The geographies of austerity. Cambridge Journal of Regions, Economy and Society, 4(3), 289-302. https://doi.org/10.1093/cjres/rsr030

Krugman, P. (1994). Competitiveness: a dangerous obsession. Foreign Affairs, 73(2), $28-44$.

OECD. (1992). Programme on Technology and the Economy. OECD publishing.

Odehnal, J., Sedlak, M., \& Michalek, J. (2012). A Competitiveness Evaluation of the Ukrainian Regions - Empirical Study. Inyinerine ekonomika - Engineering Economics, 23(4), 406-413. https://doi.org/10.5755/j01.ee.23.4.1296

Önsel, Ş., Ülengin, F., Ulusoy, G., Aktaş, E., Kabak, Ö., \& Topcu, Y. I. (2008). A new perspective on the competitiveness of nations. Socio-Economic Planning Sciences, 42(4), 221-246. https://doi.org/10.1016/j.seps.2007.11.001

Porter, M. (1990). The competitive advantage of nations. The MacMillam Press Ltd. 
Porter, M. (2000). Location, competition, and economic development: Local clusters in a global economy. Economic development quarterly, 14(1), 15-34. https://doi.org/10.1177\%2F089124240001400105

Samuelson, P., \& Nordhaus, (2011). Ekonomija. Mate.

Snieška, V., \& Bruneckienè, J. (2009). Measurement of Lithuanian regions by regional competitiveness index. Inžinerinè ekonomika, (1), 45-57.

Rozmahel, P., Issever Grochova, L., \& Litzman, M. (2014). Evaluation of Competitiveness in the European Union: Alternative Perspectives. 17th International Conference Enterprise and Competitive Environment 2014, 575-581. https://doi.org/10.1016/S2212-5671(14)00381-5

Schwab, K. (2019). The Global Competitiveness Report 2019. World Economic Forum.

Sener, S., \& Saridogan, E. (2011). The Effects of Science-Technology-Innovation on Competitiveness and Economic Growth. Procedia - Social and Behavioral Sciences, 24, 815-828. https://doi.org/10.1016/j.sbspro.2011.09.127

Trabold, H. (1995). Die internationale Wettbewerbsfähigkeit einer Volkswirtschaft. Vierteljahrshefte zur Wirtschaftsforschung, 64(2), 169-185.

Ulengin, F., Ulengin, B., \& Önsel, S. (2002). A power-based measurement approach to specify macroeconomic competitiveness of countries. Socio-Economic Planning Sciences, 36(3), 203-226. https://doi.org/10.1016/S00380121(01)00021-0

Received: 26 October, 2021; Accepted: 10 November, 2021.

Rad je primljen: 26.10.2021; Prihvaćen: 10.11.2021. 
